\title{
PERBEDAAN BERKUMUR LARUTAN KULIT MANGGIS DENGAN ANGGUR MERAH TERHADAP PEMBENTUKAN PLAK PADA SISWA SMPN I KARANG INTAN KABUPATEN BANJAR KALIMANTAN SELATAN
}

\author{
Metty Amperawati ${ }^{1}$, Naning Kisworo Utami ${ }^{2}$ \\ 1.2 Poltekkes Kemenkes Banjarmasin Jur. Keperawatan Gigi \\ Email : mettyampera@gmail.com
}

\begin{abstract}
Plaque is a major factor in dental caries, gum inflammation and periodontal disease. Dental plaque contains microorganisms composed of $70 \%$ bacterial components and $30 \%$ consists of inorganic components such as calcium, phosphorus, fluoride and organic components such as carbohydrates, proteins and fats. Mangosteen skin has a therapeutic effect, which can be used to control plaque, gingivitis, halitosis, and prevent tooth decay Grape fruit (Vitis vinifera) has a variety of properties, including preventing caries by inhibiting plaque formation.

The purpose of the research is to find out the difference in gargling of mangosteen peel solution with red wine against plaque formation in students of Karang Intan 1 Public High School, Banjar Regency, South Kalimantan. This research is a quasi experiment using the Mann-Whitney test. Research results Mangosteen skin solution and red wine can inhibit plaque formation better than rinsing with plain water.

Conclusion there is no difference rinse solution mangosteen rind with red wine on plaque formation. Suggestions For the community, especially school students, they should get used to brushing their teeth, at least gargling after eating, including eating while at school, getting used to eating fruit that is beneficial for dental health.
\end{abstract}

\section{Keywords :}

Gargling, Mangosteen Skin Solution, red wine solution, plaque

Corresponding Author :

Metty Amperawati

Poltekkes Banjarmasin Jur. Keperawatan Gigi

Email : mettyampera@gmail.com
Copyright (C) 2019 Jurnal Skala Kesehatan. Politeknik Kesehatan Banjarmasin All rights reserved 
Abstrak : Plak merupakan faktor utama dalam penyakit karies gigi, radang gusi dan penyakit periodontal. Plak gigi mengandung mikroorganisme yang tersusun dari $70 \%$ komponen bakteri dan 30\% terdiri dari komponen anorganik seperti kalsium, fosfor, fluoride dan komponen organik seperti karbohidrat, protein dan lemak. Kulit manggis memiliki efek terapeutik, yaitu dapat digunakan untuk mengendalikan plak, gingivitis, halitosis, dan mencegah kerusakan gigi Buah anggur (Vitis vinifera) mempunyai berbagai macam khasiat, diantaranya bisa mencegah terjadinya karies dengan cara menghambat terjadinya pembentukan plak.

Tujuan penelitian adalah untuk mengetahui perbedaan berkumur larutan kulit manggis dengan anggur merah terhadap pembentukan plak pada siswa SMPN 1 Karang Intan Kabupaten Banjar Kalimantan Selatan. Penelitian ini adalah eksperimen semu menggunakan uji mann-whitney. Hasil penelitian Larutan kulit manggis dan anggur merah dapat menghambat pembentukan plak lebih baik daripada berkumur dengan air biasa.

Kesimpulan tidak ada perbedaan berkumur larutan kulit manggis dengan anggur merah terhadap pembentukan plak. Saran Pada masyarakat terutama siswa sekolah sebaiknya membiasakan menggosok gigi pada, minimal berkumur setelah makan termasuk makan saat di sekolah, membiasakan mengkonsumsi buah yang bermanfaat untuk kesehatan gigi.

\section{Kata Kunci :}

Berkumur, Larutan Kulit manggis, larutan anggur merah, plak 


\section{PENDAHULUAN}

Plak berperan penting dalam menyebabkan masalah kesehatan gigi dan mulut. Akumulasi plak pada jaringan lunak dan jaringan pendukung gigi yang disebabkan karena adanya mikroorganisme dapat menyebabkan karies gigi.

Plak merupakan faktor utama dalam penyakit karies gigi, radang gusi dan penyakit periodontal. Plak gigi mengandung mikroorganisme yang tersusun dari 70\% komponen bakteri dan 30\% terdiri dari komponen anorganik seperti kalsium, fosfor, fluoride dan komponen organik seperti karbohidrat, protein dan lemak (Manson dan Eley, 2004).

Selain bahan kimiawi, penggunaan bahan alami untuk kesehatan gigi dan mulut sudah banyak digunakan karena Indonesia kaya akan tumbuh-tumbuhan herbal. Beberapa hasil penelitian yang telah dilakukan penggunaan bahan alami banyak dimanfaatkan untuk tujuan kecantikan dan kesehatan. Bahan alami untuk kesehatan gigi dan mulut, misalnya kulit manggis memiliki efek terapeutik, yaitu dapat digunakan untuk mengendalikan plak, gingivitis, halitosis, dan mencegah kerusakan gigi (Putri,H.E, Agusmawanti,P, Ismail, A., 2014).

Kulit manggis mempunyai manfaat bagi tubuh seperti zat analgesik, antioksidan, antibakteri, antiinflamasi, antikarsinogen dan antiproliferasi. Senyawa kimia dalam kulit manggis memiliki peranan penting dalam menghambat pembentukan plak gigi (Sensoy, 2012).

Berdasarkan hasil penelitian yang dilakukan oleh Poeloengan, dkk., (2010), menunjukkan bahwa ekstrak kulit manggis mengandung alkaloid, saponin, triterpenoid, tannin, fenol, flavonoid, glikosid dan steroid. Ekstrak kulit manggis dengan konsentrasi $50 \%$ mampu menghambat pertumbuhan bakteri gram positif (staphylococcus aureus dan staphylococcus epidermidis) tapi tidak menghambat bakteri gram negatif (s.typhimurium dan e.coli). meningkatkan konsentrasi ekstrak kulit manggis bisa memperluas area penghambatan terhadap pertumbuhan bakteri.

Buah anggur (Vitis vinifera) mempunyai berbagai macam khasiat, diantaranya bisa mencegah terjadinya karies dengan cara menghambat terjadinya pembentukan plak karena dalam buah anggur mengandung fitokimia yang banyak terkandung dalam kulit, buah, biji anggur, antara lain golongan polifenol, flavonoid dan asam lemak yang merupakan cara pencegahan akumulasi plak secara kimia (Gerwin H, 2004 ; Nisak, N, 2005). Penelitian yang telah dilakukan sebelumnya membuktikan bahwa jus anggur pada konsentrasi 50\% dapat menghambat pembentukan plak.

Studi pendahuluan yang dilakukan di SMPN 1 Karang Intan pada bulan Januari 2018 dengan memeriksa langsung plak gigi 10 siswa didapatkan 7 siswa didapatkan rata-rata plak gigi 3,5-5 (kriteria buruk) dan 3 siswa didapatkan rata-rata $1,8-3,4$ (sedang).

\section{BAHAN DAN METODE}

Tujuan UmumUntuk mengetahui perbedaan berkumur larutan kulit manggis dengan anggur merah terhadap pembentukan plak pada siswa SMPN 1 Karang Intan Kabupaten Banjar Kalimantan Selatan.Tujuan Khusus Untuk mengetahui berkumur larutan kulit manggis terhadap pembentukan plak pada siswa SMPN 1 Karang Intan Kabupaten Banjar Kalimantan Selatan.

Vol 10 No. 2 Juli 2019 
Untuk mengetahui berkumur larutan anggur merah terhadap pembentukan plak pada siswa SMPN 1 Karang Intan Kabupaten Banjar Kalimantan Selatan.

Untuk mengetahui perbedaan berkumur larutan kulit manggis dengan larutan anggur merah terhadap pembentukan plak pada siswa-siswa SMPN 1 Karang Intan Kabupaten Banjar Kalimantan Selatan.

Berdasarkan analisis datanya penelitian ini merupakan penelitian analitik dengan jenis penelitian yang digunakan adalah eksperimen semu.

Populasi penelitian adalah siswa SMPN 1 Karang Intan Kabupaten Banjar Kalimantan Selatan berjumlah 76 siswa.

Pengambilan sampel secara purposive sampling yaitu dengan kriteria : 1). bersedia menjadi sampel, 2). mempunyai minimal 2 gigi indeks sebanyak 74 siswa.

Sebelum penelitian diberikan informasi (syarat menjadi sampel) dan dilakukan pembersihan plak gigi dengan menggunakan scaling manual agar kondisi subyek sama. Subyek dibagi 3 kelompok : Kelompok 1 berkumur dengan larutan kulit manggis 50\%, kelompok 2 berkumur dengan larutang anggur merah $50 \%$ dan kelompok 3 berkumur dengan air biasa (kelompok kontrol). Masing-masing subyek diberikan kumur sebanyak $20 \mathrm{ml}$ selama 60 detik, dua kali sehari (pagi hari setelah makan pagi dan malam sebelum tidur), subyek tidak diperbolehkan gosok gigi dan berkumur dengan produk lain selama waktu penelitian. Berkumur dilakukan selama 3 hari. Pengukuran indeks plak satu setengah jam setelah kumur pada pagi hari, diperiksa selama 3 hari.

Data diperoleh dari data primer data yang diperoleh dengan melakukan pemeriksaan plak gigi dengan kumur-kumur larutan kulit manggis dan anggur merah, kemudian dilakukan pencatatan skor indeks plak pada responden.

Analisis data adalah setelah data diperoleh, dikumpulkan, diolah dan dianalisis kemudian data disajikan dalam bentuk frekuensi, tabel dan selanjutnya di analisis dengan uji mann-Whitney

\section{HASIL DAN PEMBAHASAN}

Jumlah Responden yang Berkumur dengan Larutan Kulit Manggis, Anggur Merah dan Air biasa (kelompok Kontrol)

\begin{tabular}{|c|c|c|c|}
\hline No & Berkumur & Frekuensi & $\%$ \\
\hline 1. & Larutan Kulit Manggis & 30 & 40,54 \\
\hline 2. & Larutan Anggur Merah & 28 & 37,84 \\
\hline \multirow[t]{2}{*}{3.} & $\begin{array}{l}\text { Air Biasa (kelompok } \\
\text { kontrol) }\end{array}$ & 16 & 21,62 \\
\hline & Jumlah & 74 & 100 \\
\hline
\end{tabular}

responden yang berkumur dengan larutan kulit manggis lebih banyak daripada yang berkumur dengan larutan anggur merah dan air biasa (kelompok kontrol).

Vol 10 No. 2 Juli 2019 
Skor Pembentukan Plak selama 5 hari sebelum dan sesudah Berkumur dengan Larutan Kulit Manggis, Anggur Merah dan Air biasa

\begin{tabular}{c|l|c|c}
\hline No. & \multicolumn{1}{|c|}{ Konsumsi } & Sebelum & Sesudah \\
\hline 1. & Larutan Kulit Manggis & 0 & 0,13 \\
\hline 2. & Larutan Anggur Merah & 0 & 0,12 \\
\hline 3. & $\begin{array}{l}\text { Air Biasa (kelompok } \\
\text { kontrol) }\end{array}$ & 0 & 0,76 \\
\hline
\end{tabular}

Pembentukan plak selama 5 hari didapatkan yang mengalami lebih cepat pembentukan plak gigi adalah kelompok kontrol dengan berkumur dengan air biasa. Sebelum dilakukan perlakuan berkumur gigi responden dilakukan pembersihan plak (skaling) sehingga skor sebelum perlakuan sama yaitu o (nol).

Perbedaan Berkumur dengan Larutan Kulit Manggis dengan Anggur Merah Terhadap Pembentukan Plak

\begin{tabular}{l|r}
\hline & \multicolumn{1}{|c}{ plak1 } \\
\hline Mann-Whitney U & 389.000 \\
Wilcoxon W & 795.000 \\
Z & -.519 \\
Asymp. Sig. (2- & .604 \\
tailed)
\end{tabular}

Setelah dilakukan uji Mann Whitney didapatkan hasil $p>0,05$ artinya tidak ada perbedaan antara berkumur larutan kulit manggis dengan anggur merah terhadap pembentukan plak.

Perbedaan Berkumur dengan Larutan Kulit Manggis dengan Air (kelompok kontrol) Terhadap Pembentukan Plak

\begin{tabular}{lr|}
\hline & plak2 \\
\hline Mann-Whitney U & 14.000 \\
Wilcoxon W & 479.000 \\
Z & -5.321 \\
Asymp. Sig. (2-tailed) & .000 \\
\hline
\end{tabular}

Setelah dilakukan uji Mann Whitney didapatkan hasil $p<0,05$ artinya ada perbedaan antara berkumur larutan kulit manggis dengan air biasa (kelompok kontrol) terhadap pembentukan plak. 
Perbedaan Berkumur dengan Larutan Anggur Merah dengan Air (kelompok kontrol) Terhadap Pembentukan

Plak

\begin{tabular}{l|r}
\hline & \multicolumn{1}{|c}{ plak3 } \\
\hline Mann-Whitney U & 13.000 \\
Wilcoxon W & 419.000 \\
Z & -5.288 \\
Asymp. Sig. (2- & .000 \\
tailed)
\end{tabular}

Setelah dilakukan uji Mann Whitney didapatkan hasil $p<0,05$ artinya ada perbedaan antara berkumur larutan kulit manggis dengan air biasa (kelompok kontrol) terhadap pembentukan plak.

Penelitian ini dilakukan pada 74 siswa kelas 7, 8, dan 9 SMPN 1 Karang Intan Kabupaten Banjar yang terbagi 3 kelompok yaitu 30 siswa kelas 7 berkumur dengan larutan kulit manggis, 28 siswa kelas 8 berkumur dengan larutan anggur merah dan 16 siswa kelas 9 berkumur dengan air biasa. Hari pertama kunjungan dilakukan pembersihan plak pada gigi indeks, sehingga nilai plak semua sampel adalah 0 (nol). Hasil penelitian selama 5 hari menunjukkan bahwa tidak ada perbedaan berkumur larutan kulit manggis dengan anggur merah terhadap pembentukan plak. Berkumur dengan larutan kulit manggis dan anggur merah selama 5 hari didapatkan ada hambatan pembentukan plak dibandingkan hanya berkumur dengan air biasa.

kulit manggis mengandung xanthone, saponin, tannin dan flavonoid yang menurut beberapa penelitian mempunyai aktivitas antiinflamasi dan antibakteri Xanthone merupakan substansi kimiawi yang tergolong senyawa polifenol. Polifenol sebagai antioksidan bekerja dengan menghambat radikal bebas yang berperan penting dalam patogenesis inflamasi akut maupun kronis. Tannin dalam konsentrasi rendah mampu menghambat pertumbuhan bakteri, sedangkan pada konsentrasi tinggi mampu bertindak sebagai antibakteri (Poeloengan)

Kulit manggis mempunyai manfaat bagi tubuh seperti zat analgesik, antioksidan, antibakteri, antiinflamasi, antikarsinogen dan antiproliferasi. Senyawa kimia dalam kulit manggis memiliki peranan penting dalam menghambat pembentukan plak gigi (Sensoy, 2012).

Kandungan yang berperan sebagai zat aktif antibakteri dalam kulit buah manggis adalah flavonoid, tanin, dan saponin. Kandungan flavonoid dapat menyebabkan metabolisme bakteri terganggu, tanin bekerja sebagai antimikroba, sedangkan saponin ketika berinteraksi dengan bakteri, maka bakteri tersebut akan lisis atau pecah (Poeloengan, M., dan Praptiwi., 2010). Saponin diduga melakukan mekanisme antibakteri dengan cara melakukan perlekatan pada lapisan biofilm pada streptococcus mutan (Vasconceles, et all.2006). Salah satu ikroorganisme Streptococcus mutans yang terdapat pada plak merupakan salah satu penyebab karies gigi (Nishimura J, Saito T, Yoneyama H, Bai LL, Okumura K, Isogai E. 2012)

Vol 10 No. 2 Juli 2019 
Hambatan pembentukan plak gigi terjadi karena anggur merah mempunyai kandungan kimia berupa flavonoid, tanin, katekin, dan fitokimia (Bhale.S., Somawane,N., 2011).

Flavonoid dalam buah anggur merupakan senyawa kimia yang mempunyai peranan penting dalam menghambat pembentukan plak (Sensoy, R. I. G, 2012). Flavonoid mempunyai sifat antibakteri karena flavonoid memiliki kemampuan merusak protein ektraselular dan dapat merusak dinding sel bakteri (kedage, V., et all 2007).

Tanin mempunyai aktivitas mengurangi perlekatan bakteri pada permukaan gigi sehingga dapat menghambat pembentukan plak gigi (Akiyama, H., Fuji, K., Yamasaki, O., 2001).

Senyawa katekin pada anggur merah dapat menghambat pembentukan plak melalui penghambatan proses glikolisasi dengan cara bekerja secara kompetitif dengan enzim glukosiltransferase, sehingga pembentukan polisakarida ekstraseluler oleh bakteri terhambat (Van, P.H., Backer, D., 1993)

Kandungan fitokimia dalam buah anggur mempunyai aktivitas penghambatan plak dengan cara menghalangi enzim-enzim yang berhubungan dengan pembentukan matriks polisakarida plak, mencegah perlekatan bakteri pada permukaan gigi, mencegah pembentukan asam oleh bakteri dan mengurangi mikroorganisme kariogenik (Metaliri, M., Utami, S., Joenoes, H., 2010)

\section{KESIMPULAN}

1. Berkumur larutan kulit manggis pada siswa SMPN 1 Karang Intan Kabupaten Banjar Propinsi Kalimantan Selatan terjadi pembentukan plak sebesar 0,13 dan berkumur dengan larutan anggur merah terjadi pembentukan plak 0,12 lebih baik dibanding dengan berkumur dengan air biasa terjadi pembentukan plak sebesar 0,76

2. Tidak ada perbedaan berkumur larutan kulit manggis dengan anggur merah terhadap pembentukan plak di SMPN 1 Karang Intan Kabupaten Banjar Propinsi Kalimantan Selatan.

\section{DAFTAR PUSTAKA}

Akiyama, H., Fuji, K., Yamasaki, O., 2001, Antibacterial Action of Several Tannins Against Staphylococcus aureus, Journal of Antimicrobial Chemotherapy., 48 : 487-491.

Bhale.S., Somawane,N., 2011, Anti Inflammatory Potential of Alcoholic Extract of Resvaretrol from Fruits of Vitis vinifera Linn. J. Res Pharm. Scie 2(2) : 271275

Kedage, V., Tilak, J., Dixit, G., Devasagam, T., Mhatre, M., 2007, A Study of Antioxidant Properties of Some Varieties of Grapes (Vitis vinifera L), Criticl Reviews in Food Scie and Nutr., 47 : 175-185.

Manson dan Eley, 2004, Etiologi Penyakit Periodontal. Buku Ajar Periodotia (Outline of Periodontics), Jakarta, Hipokrates

Metaliri, M., Utami, S., Joenoes, H., 2010, Antimicrobial Activity of Grape 
Skin (Vitis vinifera) Infusum on Salivary Mutans Streptococci, Ind. J of Dent Research., 17 (1) : 15-19.

Nisak, Nasichatun.,2005, Pengaruh Pemberian Jus Buah Anggur ( vitis vinifera ) terhadap Pembentukan Plak Gigi. Artikel publikasi ilmiah. Fakultas Kedokteran. Institutional Repository (UNDIP-IR). Universitas Diponegoro, Semarang.

Nishimura J, Saito T, Yoneyama H, Bai LL, Okumura K, Isogai E. 2012, Biofilm formation by streptococcus mutans and related bacteria. Advances in Microbiology Sept; (2).p.208- 15.

Poeloengan, M., dan Praptiwi., 2010. Uji Aktiitas Antibakteri Ekstrak Kulit Buah Manggis (Garcinia Mangostana Linn.), Media Litbang Kesehatan, XX : 68.

Putri,H.E, Agusmawanti,P, Ismail, A., 2014, Pengaruh Berkumur Sari Buah Anggur Merah berbagai Konsentrasi dan Chlorhexidine 0,12\% terhadap Indeks Plak, ODONTO Dental Journal.Volume 1.Nomor 1.Mei

Sensoy, R. I. G., 2012. Determination Of Phenolic Substances And Antioxidant Activities In Some Grape Cultivars By Hplc, J. Anim. Plant Sci., 448-451.

Sriyono, R,A,N, Andriani,I.,2013, Daya Antibakteri Ekstrak Etanol Kulit Manggis (Garcinia Mangostana Linn.) Terhadap Bakteri Porphyromonas Gingivalis Antibacterial power Ethanol Extract Skin Mangosteen (Garcinia Mangostana Linn.) Against bacteria Porphyromonas gingivalis ,IDJ, Vol. 2 No. 2, Yogyakarta

Van, P.H., Backer, D., 1993, Ilmu Kedokteran Gigi Pencegahan, Yogyakarta : Gadjah Mada University Press., h. 59-101.

Vasconceles, et all.2006. Minimum Inhibitory Concentrations of Adherence of Punica granatum Linn Gel Againts S. mutans, S. midis, and C. Albicans. Brazil. Braz Dent J Vol 17(3):233-227 